BHI-01240

Rev. 0

\title{
ALARA Review for the 221-U Characterization
}

Prepared for the U.S. Department of Energy, Richland Operations Office Office of Environmental Restoration

Submitted by: Bechtel Hanfond, Inc. 
TRADEMARK DISCLAIMER

Reference herein to any specific commercial product, process, or service by trade name, trademark, manufacturer, or otherwise, does not necessarily constitute or imply its endorsement, recommendation, or favoring by the United States Government or any agency thereof or its contractors or subcontractors.

This report has been reproduced from the best available copy. Available in paper copy and microfiche.

Available to the U.S. Department of Energy and its contractors from

Office of Scientific and Technical Information

P.O. Box 62

Oak Ridge, TN 37831

(615) 576-8401

Available to the public from the U.S. Department of

Commerce

National Technical Information Service

5285 Port Royal Road

Springfield, VA 22161

(703) $487-4650$

Printed in the United States of America

DISCLM-5.CHP (8-91) 
BHI-01240

Rev. 0

OU: N/A

TSD: N/A

ERA: N/A

\section{APPROVAL PAGE}

Title: $\quad$ ALARA Review for the 221-U Characterization

Approval: $\quad$ D. E. Gergely, Manager, Radiological Controls
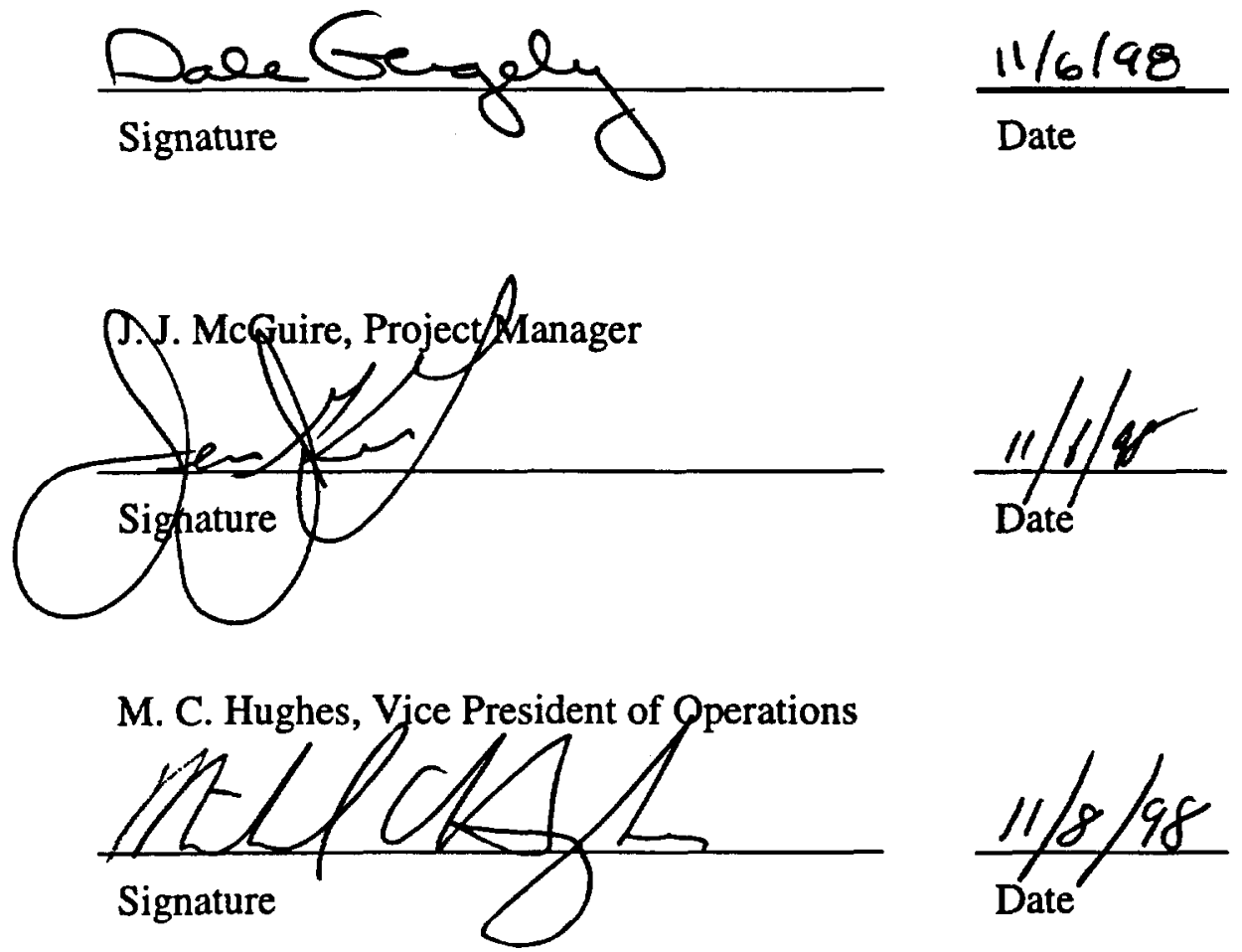
BHI-01240

Rev. 0

\title{
ALARA Review for the 221-U Characterization
}

\author{
Authors
}

T. A. Edwards

Thermo-Hanford, Inc.

Date Published

November 1998 
BHI-01240

Rev. 0

\section{CONTENTS}

\begin{tabular}{|c|c|}
\hline 0 & INTRODUCTION ........ \\
\hline 2.0 & DESCRIPTION OF PROJECT \\
\hline 3.0 & EXPOSURE ESTIMATE .................. \\
\hline 4.0 & 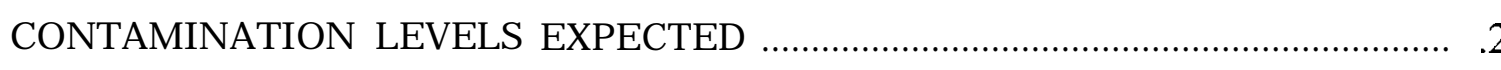 \\
\hline 5.0 & EXPOSURE CONTROL \\
\hline 6.0 & 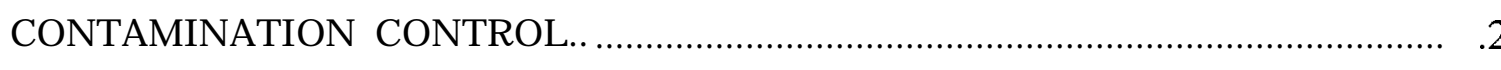 \\
\hline 7.0 & AIRBORNE RADIOACTIVITY CONTROLS \\
\hline 8.0 & 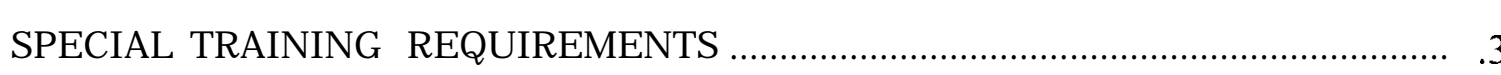 \\
\hline 9.0 & CONCLUSION \\
\hline
\end{tabular}

\section{APPENDICES}

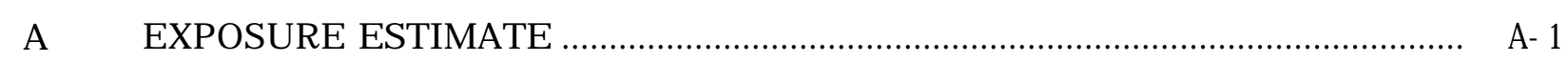

B CONTAMINATION AND AIRBORNE RADIOACTIVITY CONTROLS................... B-1

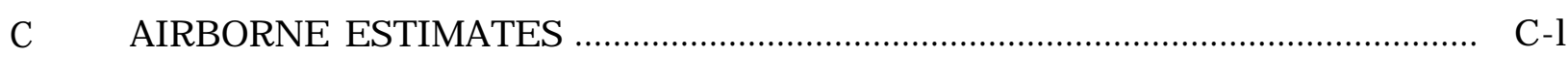


BHI-01240

Rev. 0

\subsection{INTRODUCTION}

The following as low as reasonably achievable (ALARA) review provides a description of the engineering and administrative controls used to manage personnel exposure, control contamination levels, and control airborne radioactivity concentrations while conducting surveillance and maintenance (S\&M) and Canyon Disposition Initiative (CDI) effort activities at the U Plant 221-U Building (Canyon and Galleries) located in the 200 West Area of the Hanford Site.

\subsection{DESCRIPTION OF PROJECT}

U Plant was constructed in 1944 as one of three original chemical separation plants to support plutonium production during World War II. The 221-U Building was never used for plutonium extraction because the other two plants (T Plant and B Plant) met the production needs. The plant was converted to process uranium in 1952 and was placed on standby in 1958. No written record of the U Plant deactivation exists; therefore, the quantity, form, and distribution of the hazardous material are uncertain. This uncertainty is increased because from 1958 to 1964 , U Plant was used to receive, decontaminate, and maintain contaminated equipment from other Hanford processing facilities. Isotopic information obtained indicates that the majority of the radionuclides of concern are cesium-137 and strontium-90. To a lesser extent, uranium and plutonium may be expected.

Activities that will be performed under S\&M and CDI activities covered under this formal ALARA review are as follows:

- $\quad \mathrm{S} \& \mathrm{M}$ of facility barriers and postings

- $\quad$ Minor maintenance

- $\quad$ Pre-job walk downs

- Radiological surveys to support work planning activities and verify contamination levels.

\subsection{EXPOSURE ESTIMATE}

The exposure estimate is based on current contamination data and external dose rate surveys of the work area. The total effective dose equivalent is estimated to be no greater than 600 personmrem (see Appendix A for additional information on the exposure estimate). 
BHI-01240

Rev. 0

\subsection{CONTAMINATION LEVELS EXPECTED}

A radiological survey of the 221-U area near Section Twenty One detected loose surface contamination levels from $100 \mathrm{dpm} / 100 \mathrm{~cm}^{2}$ to $700 \mathrm{dpm} / 100 \mathrm{~cm}^{2}$ alpha and $1,000 \mathrm{dpm} / 100 \mathrm{~cm}^{2}$ to as high as $121 \mathrm{mrad} / \mathrm{cm}^{2}$ (uncorrected) beta in the work area.

Decontamination activities occurred in 1996 to provide an S\&M pathway for inspections. Contamination levels based on historical surveys indicate that the potential to encounter greater than $1,000,000 \mathrm{dpm} / 100 \mathrm{~cm}^{2}$ removable beta/gamma does exist in some areas. The radiation survey reports indicate removable contamination as high as $600 \mathrm{mrad} / \mathrm{hr}$ (beta) was measured. Contamination is also expected to be fixed on equipment. Surveys indicate that contamination fixed on equipment was reading as high as $15,000 \mathrm{mrad} / \mathrm{hr}$ (beta). It is anticipated that contamination levels in this range will be measured.

\subsection{EXPOSURE CONTROL}

General area dose rates are as high as $2 \mathrm{mrem} / \mathrm{hr}$ when the cover blocks are in place. Dose rates from historical data indicate that the dose rates range from $10 \mathrm{mrem} / \mathrm{hr}$ to $1,000 \mathrm{mrem} / \mathrm{hr}$ above a cell when the cover block was removed. Because of higher beta readings, shielding materials will be provided to minimize the beta dose as appropriate. It should be noted that cover block removal is not included in this ALARA review because the work activities will be done remotely.

\subsection{CONTAMINATION CONTROL}

Contamination control will be accomplished by using a combination of administrative and engineered controls.

Administrative controls include specified contamination limits in the radiological work permit, radiological control hold points in task instructions, dress/undress practices, and training. Administrative controls are used where specific engineered controls do not provide necessary and adequate guidance to personnel.

Engineering controls are used to control the spread of surface contamination and to reduce the level and the extent of airborne contamination. Appendix B identifies the engineered controls for contamination during the activities stated in Section 2.0, "Description of Project." 
BHI-01240

Rev. 0

\subsection{AIRBORNE RADIOACTIVITY CONTROLS}

The air sampling assessment (TA-98-AS-15) provides guidance to radiological control technicians regarding air sampling requirements during air sampling activities.

Containing contamination is an essential part of controlling airborne radioactivity. Controls such as the ones identified in Appendix B are an essential part of controlling airborne contamination levels. Respiratory protection will be required for the above work activities. Airborne estimates are contained in Appendix C.

\subsection{SPECIAL TRAINING REQUIREMENTS}

Personnel assigned to work on the 221-U Facility are required to complete a pre-job briefing and must receive training in the following: Radiation Worker II, General Employee Training/Hanford General Employee Radiological Training, facility orientation, and 40-Hour Hazardous Worker Training. Personnel will be required to wear respiratory protection to include air purifying respirators and positive air purifying respirators with hoods and/or masks.

\subsection{CONCLUSION}

The work activities in and around the $221-\mathrm{U}$ work area use sound ALARA practices and principles. The incorporated engineering, contamination area, and airborne radioactivity controls should ensure that all exposures are maintained ALARA. Implementation of the engineering and administrative controls results in an estimated total effective dose equivalent of 600 personmrem. 
BHI-01240

Rev. 0

APPENDIX A

EXPOSURE ESTIMATE 
Job Title: S\&M inspections, minor repairs, and surveys

Field Engineer: D.R. Baker

\begin{tabular}{|c|c|c|c|c|c|c|c|c|}
\hline $\begin{array}{c}\text { Task } \\
\#\end{array}$ & Task Description & $\begin{array}{l}\text { Work } \\
\text { Area } \\
\text { Hours }\end{array}$ & $\begin{array}{c}\text { Number } \\
\text { of } \\
\text { People }\end{array}$ & $\begin{array}{c}\text { Exposure } \\
\text { Rate } \\
(m r e m / h r)\end{array}$ & $\begin{array}{c}\text { Estlmated } \\
\text { External } \\
\text { Exposure }\end{array}$ & $\begin{array}{c}\text { Estimated } \\
\text { Air } \\
\text { Activity } \\
(D A C)\end{array}$ & $\begin{array}{l}\text { DAC } \\
\text { Hours }\end{array}$ & $\begin{array}{l}\text { TEDE } \\
\text { for } \\
\text { Task }\end{array}$ \\
\hline 1 & Inspections & 40 & 3 & 0.5 & 60 & $<0.1$ & $<0.9$ & 60 \\
\hline 2 & Minor maintenance & 40 & 3 & 0.5 & 60 & $<0.1$ & $<0.9$ & 60 \\
\hline 3 & Surveys & 80 & 3 & 2.0 & 480 & $<0.1$ & $<0.9$ & 480 \\
\hline \multicolumn{9}{|l|}{4} \\
\hline \multicolumn{9}{|l|}{5} \\
\hline \multicolumn{9}{|l|}{6} \\
\hline \multicolumn{9}{|l|}{7} \\
\hline \multicolumn{9}{|l|}{8} \\
\hline \multicolumn{9}{|l|}{9} \\
\hline \multicolumn{9}{|l|}{10} \\
\hline \multicolumn{9}{|l|}{11} \\
\hline \multicolumn{9}{|l|}{12} \\
\hline \multicolumn{9}{|l|}{13} \\
\hline \multicolumn{9}{|l|}{14} \\
\hline \multicolumn{9}{|l|}{15} \\
\hline \multicolumn{9}{|l|}{16} \\
\hline \multicolumn{9}{|l|}{17} \\
\hline \multicolumn{9}{|l|}{18} \\
\hline \multicolumn{9}{|l|}{19} \\
\hline \multicolumn{9}{|l|}{20} \\
\hline 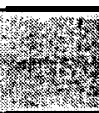 & & 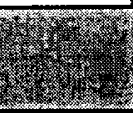 & 807 & $\begin{array}{l}3 \times 18 \\
6\end{array}$ & (T) & Estimate & $\begin{array}{l}\text { TEDE } \\
\text { r Work }\end{array}$ & 600 \\
\hline
\end{tabular}

NOTE. Estimated Air Activity is breathing zone air activity, taking into account protection factor of respiratory protection, if used.

NOTE. Use 2.5 mrem exposure per DAC. 
BHI-01240

Rev. 0

APPENDIX B

CONTAMINATION AND AIRBORNE RADIOACTIVITY CONTROLS

B-1 
BHI-01240

Rev. 0

\section{APPENDIX B}

\section{CONTAMINATION AND AIRBORNE RADIOACTIVITY CONTROLS}

- The radiological control technician will perform a survey of the area prior to work beginning in previously inaccessible area.

- $\quad$ Only take necessary material into the work area.

- Wrap clean equipment and power cords to prevent them from contamination.

- Continually wipe down all work areas to help maintain contamination levels in the work area as low as reasonably achievable.

- Building ventilation must be operating when any work is being performed in the Canyon and Galleries.

- Glovebags and containment tents will be used to minimize the spread of contamination as appropriate.

- $\quad$ Misting and damp cloths will be used to decontaminate high levels of contamination to help prevent airborne radioactivity and control the spread of contamination as appropriate.

- Materials will be provided to shield high beta dose rates as appropriate 
BHI-01240

Rev. 0

APPENDIX C

AIRBORNE ESTIMATES

C-1 
BHI-01240

Rev. 0

\section{Estimation of Airborne \\ 221-U Canyon}

The methods for calculation and typical parameter values are from BHI-SH-02 Vol. 2 procedure 2.2.2, "Estimation of Airborne Radioactivity levels".

Prepared by: TA Edwards

Work Package \#:

N/A

Location: $221-U$ canyon and galleries

$$
\mathrm{C}=4.5 \mathrm{E}-7(\mathrm{Cl} \text { or } \mathrm{C2})(\mathrm{Aw})(\mathrm{RF})(\mathrm{Fa}) /(\mathrm{AC})(\mathrm{Vr})
$$

$\mathrm{C}=$ Average workplace air concentration $\left(\mathrm{uCi} / \mathrm{cm}^{3}\right)$

$\mathrm{Cl}=$ Beta/gamma surface contamination level $\left(\mathbf{d p m} / \mathbf{c m}^{2}\right)$

C2 = Alpha surface contamination level $\left(\mathbf{d p m} / \mathbf{c m}^{2}\right)$

$6.00 E+08$

1.E+05

Aw = Surface area being worked on per hour $\left(\mathrm{cm}^{2} / \mathrm{h}\right)$

$3.00 E+03$

$\mathrm{RF}=$ Release fraction

$\mathbf{F a}=$ Containment/ventilation adjustment factor

$\mathrm{AC}=$ Number of air changes per hour $\left(\mathbf{h}^{-\mathbf{t}}\right)$

$\mathrm{Vr}=$ Volume of air in room or enclosure containing the operation $\left(\mathrm{cm}^{3}\right)$

1.00E-06

4.5E-7 = Converts dpm to $\mathrm{uCi}$

$\begin{array}{lll}\mathrm{Cl}= & & 2.23 \mathrm{E}-11 \\ \mathrm{C} 2= & & 5.21 \mathrm{E}-15\end{array}$

Estimated DAC Sr290 = 0.011174

Estimated DAC Pu-239 $=\quad 0.002607$

DAC Equivalent $\quad 0.013781$

With Respiratory PF $\quad 0.013781$

Assumptions \ limiting conditions:

1. Average area disturbed/hour at $600 \mathrm{mrad} / \mathrm{hr}$ reading.

2. Contamination data is based on conservatively high contamination levels

3. The room volume is a conservative value based on actual total volume.

4. Release fraction is based on non-disruptive work such as taking a smear

5. Containment adjustment not considered

6. Number of air changes per hour is based on the size of the canyon and the rated capacity of system

7. Airborne is assumed to be eventy distributed throughout the room. Airborne levels in the immediate area of generation could be higher by a factor of 2 or more.

8. Estimated DAC and DAC equivalent do not include respiratory protection factors.

9. DAC equivalent is the total of alpha and beta/gamma estimated DAC values.

10. 'With Respiratory Protection Factor' column divides DAC equivalent by 1 for use of no respiratory protection.

11. DAC values used is for class W Pu. This is conservative because Uranium DAC values are higher

Note: PAPR's (PF 1000 will be used until characterization is complete. 
BHI-01240

Rev. 0

\section{DISTRIBUTION}

\section{ERC Team}

J. C. Craig, THI X $\quad$ X-23

R. G. Egge, BHI S3-21

G. L. Funnell, BHI T7-05

M. J. Galgoul, CHI H9-03

D. E. Gergely, BHI H0-15

J. J. McGuire, BHI S3-20

V. E. Shockley, BHI X0-34

R. G. Shuck, BHI T7-05

T. A. Edwards, THI X9-09

S. L. Winslow, BHI X0-23

P. J. Woods, BHI S3-20

S/M\&T Project Files S3-20

Document Information Services (3) H0-09

DOE-RL Public Reading Room H2-53

Hanford Technical Library P8-55

RadCon Engineering File/LB X0-34 